Article

\title{
Mixed Signals: Democratization and the Myanmar Media
}

\author{
Tina Burrett \\ Faculty of Liberal Arts, Sophia University, 102-8554 Tokyo, Japan; E-Mail: tburrett@sophia.ac.jp
}

Submitted: 5 December 2016 | Accepted: 20 March 2017 | Published: 13 April 2017

\begin{abstract}
This article investigates the media context of Myanmar's recent political reforms and transition of power. Drawing on interviews with 57 Yangon-based media professionals, the article analyzes the media's role as both an agent and subject of political change as Myanmar prepared for parliamentary elections in November 2015. It asks to what extent changes in the Myanmar media system adhere to existing theories of the media's role in the democratization process. Specifically, the article analyzes the features and functions of Myanmar's media during the country's liberalization from 2010 to 2015. The article concludes by assessing what Myanmar's experience adds to our theoretical understanding of the media's transformation during liberalization.
\end{abstract}

\section{Keywords}

Burma; democratization; freedom of the press; journalism; liberalization; media; Myanmar; reform; transition

\section{Issue}

This article is part of a multidisciplinary issue of Politics and Governance, edited by Andrej J. Zwitter (University of Groningen, The Netherlands) and Amelia Hadfield (Canterbury Christ Church University, UK).

(C) 2017 by the author; licensee Cogitatio (Lisbon, Portugal). This article is licensed under a Creative Commons Attribution 4.0 International License (CC BY).

\section{Introduction}

2016 was a monumental year in Myanmar. Parliamentary elections in November 2015 delivered a landslide victory for Aung San Suu Kyi's National League for Democracy (NLD). In March 2016, the NLD's Htin Kyaw became Myanmar's first civilian president since the military coup in 1962, a role denied to Aung San Suu Kyi by the juntadrafted constitution because she married a foreigner. The NLD's 2015 election victory is the culmination of a five-year reform process. In March 2011, Myanmar's ruling junta handed power to a new nominally civilian government, led by former general President Thein Sein. The new president initiated a series of reforms leading to a substantial opening of the former pariah state (Hlaing, 2012). Most dramatically, these reforms include allowing Aung San Suu Kyi and the NLD to contest parliamentary by-elections in April 2012, following her release from house arrest in November 2010. Reforms also included releasing hundreds of political prisoners, reaching preliminary peace agreements with the majority of armed ethnic groups and gradually reducing restrictions on media freedom. In August 2012, Thein Sein's government abolished the Ministry of Information's pre-publication censorship regime (Harris, 2013). Previously off-limits topics such as rampant corruption, inequality, ethnic conflicts, and government land-grabs began to feature frequently on the front pages.

Myanmar's media have been center stage in the country's transition process, both as a subject and agent of change. Media and politics influence each other. This article investigates the media's role in Myanmar's democratization during the five-year liberalization process preceding parliamentary elections in November 2015. Myanmar was selected as an illustrative case against which to compare existing theories of the media's functions and features during liberalization for the purpose of both testing and refining these theories.

To develop a more nuanced understanding of the conditions and consequences of the Myanmar media's involvement in the democratization process, the article draws a distinction between structure and agency. The structural dimensions refer to the economic, technological and political context in which the media operate. Agency denotes the editorial aspects of the media. Journalists play an active role in constructing social reality, 
by setting the agenda for public discourse and by framing narratives that give meaning to political events. The interplay between structure and agency creates the opportunities and constraints that shape both the media's influence on democratic change and the impact of political change on the media.

\section{The Media and Democratization}

Before analyzing the media as a factor in political change, it is first necessary to define democratization. At its most simple, democratization is a journey between two ideal points on the political spectrum: closed autocracy at one end and open democracy at the other. In reality, no regime conforms to an ideal type (Dahl, 1998). Autocracy and democracy are both contested concepts that describe a range of real-world regimes. Likewise, there are many paths between these two points. Scholars of democratization have tried to identify the regular steppingstones that mark this journey. A developmental theory of democratization assumes linear progress along sequential steps. The most widely used schema distinguishes between three main stages of democratization: liberalization of the autocratic regime; transition to democratic rule; and the consolidation of the new democratic order (O'Donnell \& Schmitter, 1986). The process of regime change, however, is not always linear. Timing and sequencing vary between cases. In some states, different stages can occur simultaneously. Some states may skip one stage altogether. Others go back as well as forward along the path to democracy. Myanmar's democratization has been far from straightforward. In November 2014, Aung San Suu Kyi declared that the international community had been too optimistic about the results of liberalization begun in 2010 (Tha, 2014). Media freedom and human rights groups concurred, arguing that 2014 witnessed significant backsliding (Committee to Protect Journalists, 2014b; Human Rights Watch, 2015). Thomas Carothers argues that many states get stuck at the transition stage and never arrive at consolidated democracy (2002). To account for the range of routes, Schneider and Schmitter (2004) refer to liberalization, transition and consolidation as 'components' rather than phases of democratization.

The distinction between the three components of democratization is a useful conceptual tool for media scholars. As Katrin Voltmer theorizes that, depending on the particular component of the democratization processliberalization, transition or consolidation-the media affect the course of events in different ways (2013, p. 72). At the same time, changes in political circumstances alter the constraints and opportunities for journalists and other media professionals. This article looks at the Myanmar's media as the country liberalized between 2010 and 2015. During liberalization, authoritarian leaders loosen their grip on society, allowing citizens more personal, professional and political freedom. Relaxing media censorship is an important part of this process. Liberalization is often a strategic response by the ruling elite to maintain their power in reaction to mounting domestic and external pressure for political change. Domestically, the impetus for liberalization can be top-down or bottomup. In Myanmar's case, a combination of poor development prospects, unrest among large sections of the population, an effective opposition movement, and Western sanctions that deepened economic dependence on China, convinced the ruling regime to initiate a largely top-down liberalization process as a means to retain control over the direction of political change.

\section{Approach and Methods}

Voltmer theorizes that the functions performed by the media in liberalizing autocracies vary depending on the impetus for liberalization (2013, p. 79). Based on her comparative research, she distinguishes between three models of liberalization based on the direction and origins of political change: bottom-up; top-down; and external influences. In reality these three processes are often interdependent. And as Voltmer points out, external influences are unlikely to trigger liberalization independently of the preferences of domestic actors.

Voltmer's work offers a rare attempt to conceptualize a general theory of the media's role in the liberalization process. Her theories are the starting point for my analysis. I assess to what extent the Myanmar media exhibited the features and function associated with her three interdependent models during the country's liberalization by answering the following research question:

To what extent do Voltmer's theories of the role of the media in political liberalization explain the liberalization of Myanmar's media?

To further structure my analysis of the Myanmar media as a subject and agent of political change, I draw on Hallin and Mancini's (2004) four dimension comparative framework of media systems. First, journalistic professionalism denotes the norms that constitute the media's professional identity and that inform the standards of news reporting. Second, political parallelism describes the ties that the media develop with political interest groups within society. Third, the media are strongly influenced by the state, a relationship that involves elements of both dependency and enmity. Finally, the media are embedded within economic markets. In borrowing from Hallin and Mancini I hope to enhance the relevance of my study to comparativists working to refine typologies of media systems, as well as to add to the scholarly debate on the role of the media in democratization. My theoretical approach is set out in Table 1.

As Table 1 shows, Voltmer's three liberalization models are divided into four dimensions based on Hallin and Mancini's media systems framework. Although my analysis of the Myanmar media is divided into four distinct dimensions, this does not imply that transformations 
Table 1. Features and functions of the media system during liberalization. Source: Voltmer (2013, pp. 79-92); Hallin and Mancini (2004).

\begin{tabular}{|c|c|c|c|c|}
\hline & & Bottom-up Liberalization & Top-down Liberalization & Externally-Influenced Liberalization \\
\hline \multirow{2}{*}{ 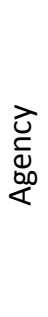 } & \multirow{2}{*}{ 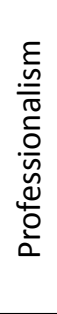 } & $\begin{array}{l}\text { Partisanship prioritized over } \\
\text { objective and accurate } \\
\text { reporting }\end{array}$ & $\begin{array}{l}\text { Ritualized rhetoric of the state } \\
\text { media replaced by more } \\
\text { accessible language }\end{array}$ & $\begin{array}{l}\text { Prioritizing of information } \\
\text { delegitimizing the regime and } \\
\text { rallying popular resistance }\end{array}$ \\
\hline & & $\begin{array}{l}\text { Content of oppositional media } \\
\text { produced by activists rather } \\
\text { than journalists }\end{array}$ & $\begin{array}{l}\text { Journalists serve the political } \\
\text { and economic interests of } \\
\text { financial backers rather than } \\
\text { the public interest }\end{array}$ & $\begin{array}{l}\text { Outsiders often misjudge the } \\
\text { domestic reception and } \\
\text { interpretation of information they } \\
\text { provide }\end{array}$ \\
\hline \multirow{7}{*}{ 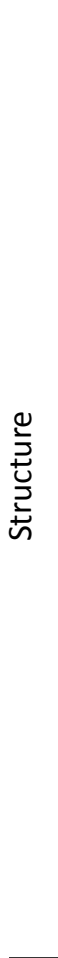 } & & $\begin{array}{l}\text { Close relationship between } \\
\text { journalists and the opposition }\end{array}$ & $\begin{array}{l}\text { Journalists alignment with one } \\
\text { of rival factions within the }\end{array}$ & $\begin{array}{l}\text { Domestically available exiled and } \\
\text { foreign media sustain opposition }\end{array}$ \\
\hline & $\underline{\underline{\underline{E}}}$ & $\begin{array}{l}\text { Media a tool to build alliances } \\
\text { across diverse opposition }\end{array}$ & $\begin{array}{l}\text { regime (hard liners or soft } \\
\text { liners) }\end{array}$ & $\begin{array}{l}\text { resolve by providing a sense of } \\
\text { solidarity }\end{array}$ \\
\hline & $\frac{\overline{0}}{\frac{\pi}{\pi}}$ & $\begin{array}{l}\text { groups divided by race and } \\
\text { class }\end{array}$ & $\begin{array}{l}\text { Liberalization deepens divisions } \\
\text { within ruling regime between } \\
\text { hard and soft liners }\end{array}$ & $\begin{array}{l}\text { Copying and distributing } \\
\text { transborder media to those who } \\
\text { cannot receive it directly expands } \\
\text { opposition network }\end{array}$ \\
\hline & \multirow{2}{*}{ 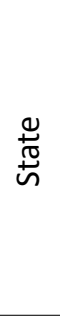 } & \multirow[t]{2}{*}{$\begin{array}{l}\text { State suppression and } \\
\text { surveillance of independent } \\
\text { media }\end{array}$} & $\begin{array}{l}\text { State grants new freedoms, but } \\
\text { for their own political purpose, } \\
\text { not as constitutional rights }\end{array}$ & \multirow{2}{*}{$\begin{array}{l}\text { State jams international } \\
\text { broadcasts and imposes stiff } \\
\text { penalties for those consuming and } \\
\text { distributing forbidden media } \\
\text { Limited access for foreign } \\
\text { journalists }\end{array}$} \\
\hline & & & $\begin{array}{l}\text { State determines scope of } \\
\text { political debate-some topics } \\
\text { remain taboo despite relaxing } \\
\text { censorship }\end{array}$ & \\
\hline & \multirow{2}{*}{ 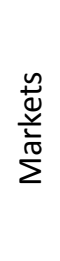 } & \multirow{2}{*}{$\begin{array}{l}\text { Pro-democracy opposition } \\
\text { have their own media } \\
\text { (including dissident and } \\
\text { underground media) that } \\
\text { challenge state media } \\
\text { narratives }\end{array}$} & $\begin{array}{l}\text { State-controlled media persists, } \\
\text { despite marketization } \\
\text { delivering some pluralism }\end{array}$ & $\begin{array}{l}\text { Opposition (including media) } \\
\text { funded by foreign donors and } \\
\text { political exiles }\end{array}$ \\
\hline & & & $\begin{array}{l}\text { Independent media largely } \\
\text { dependent on intra-regime } \\
\text { factions for economic survival }\end{array}$ & $\begin{array}{l}\text { Foreign media available in the } \\
\text { domestic market }\end{array}$ \\
\hline
\end{tabular}

within each arena are discreet. Rather, developments within each dimension of the media system, as well as cross the three models of liberalization are considered interdependent.

To reveal the changes that took place in Myanmar's media system during the country's liberalization period, my research draw on face-to-face interviews with 57 journalists, editors, media owners and trainers working in the Myanmar-based media. My methods are therefore exclusively qualitative. Interviewees' affiliations are detailed in Table 2.

Interviews conducted by the author took place primarily during two periods of fieldwork in December 2013 and December 2014. Follow-up interviews were conducted electronically between September and December 2015. Naturally, a potential problem with interview data is deliberate distortion. Given the volatility of the political situation in Myanmar, it may be professionally or legally helpful to censor one's views, or to hide knowledge of any wrongdoing. To mitigate this problem, interviewees were offered anonymity. Furthermore, multiple sources from different organizations were interviewed, and in several cases re-interviewed, to alleviate the effects of embellishment or misinformation. Where appropriate, I draw attention to conflicting accounts and opinions in my discussion below. Basing my analysis of Myanmar's media liberalization on the views of journalists working inside system, however, is a potential weakness of my study, as it is not always possible to adequately evaluate and corroborate their testimonies.

Interviewees were initially selected from among my personal contacts in the Yangon-based media. Interviewees then introduced me to their colleagues and associates, leading to a snowballing method of selection. Some interviewees proved particularly knowledgeable and were re-interviewed. My personal contacts in Myanmar work in the print media. The majority of their associates are also print journalists. This led to over representation of print journalists relative to professionals from other media sectors among my interviewees. Arguably, the print media is the most relevant sector to analyze when investigating the impact of liberalization on the Myanmar media. At the time of writing, the Myanmar government retains almost exclusive control over 
Table 2. Interviewees affiliation (no. interviewees).

\begin{tabular}{|c|c|c|c|c|c|}
\hline NGO (12) & Print (30) & Broadcast (6) & Professional Body (5) & Online* (1) & International (3) \\
\hline Tagaung Institute & 11 Media (3) & DVB (3) & Pen International & $\begin{array}{l}\text { Kamayut } \\
\text { Media }\end{array}$ & Radio Free Asia \\
\hline $\begin{array}{l}\text { BBC Media } \\
\text { Action (3) }\end{array}$ & Mizzima (3) & Skynet & $\begin{array}{l}\text { Interim Press } \\
\text { Council (3) }\end{array}$ & & New York Times \\
\hline Internews & 7 Day News (3) & Mandalay FM & $\begin{array}{l}\text { Myanmar Journalist } \\
\text { Network }\end{array}$ & & $\begin{array}{l}\text { Agence France- } \\
\text { Presse }\end{array}$ \\
\hline Open Society Institute & Street View Journal & MRTV & & & \\
\hline $\begin{array}{l}\text { Burma News } \\
\text { International (3) }\end{array}$ & $\begin{array}{l}\text { Myanmar Freedom } \\
\text { Daily (2) }\end{array}$ & & & & \\
\hline $\begin{array}{l}\text { Karen Information } \\
\text { Centre }\end{array}$ & The Chronicle (2) & & & & \\
\hline \multirow[t]{11}{*}{ Pandita Institute (2) } & Pae Tin Thran & & & & \\
\hline & Yanant Thit & & & & \\
\hline & Women Can Do It & & & & \\
\hline & Myanmar Times (2) & & & & \\
\hline & The Voice (3) & & & & \\
\hline & Arakan Journal & & & & \\
\hline & Yangon Times & & & & \\
\hline & The People's Age & & & & \\
\hline & Irrawaddy (2) & & & & \\
\hline & Chin World News & & & & \\
\hline & $\begin{array}{l}\text { Human Rights \& } \\
\text { Democracy Journal }\end{array}$ & & & & \\
\hline
\end{tabular}

Notes: Total 57 interviewees, 17 women and 40 men. ${ }^{*}$ Many print and TV media also have associated websites. Here online is used for media outlets available only on the web.

the broadcast media. Journalists at state broadcasters were reluctant to be interviewed, fearing negative consequences at the hands of their employers (only one journalist from state-owned MRTV agreed to an interview). Three journalists/editors at private satellite broadcaster DVB, currently the only Myanmar television channel not directly or indirectly owned by the state, were interviewed. The most popular online news sites in Myanmar are those run by the major newspapers (for example, Eleven Media and 7 Day News). Their online content is very similar to what appears in print and is written by the same journalists. Interviews with print journalists, therefore included questions about their publication's associated website. The sharing of news articles on social media was also discussed with all interviewees.

Interviewees were asked open-ended questions, for example:

- How has the end of official censorship influenced your work?

- Can you describe your experience of reporting on the NLD?
- How would you characterize media reporting on inter-ethnic tensions?

Care was taken to avoid phrasing questions in a manner that might elicit specific kinds of responses. Although the same general questions were asked to each interviewee, interviews did not follow a set script. Rather, interviewees were encouraged to elaborate and refine their answers with spontaneous follow up questions. Most interviews were approximately one hour to 90 minutes in length.

Following Hallin and Mancini, my discussion below is divided into four sections. In the first section, I begin by analyzing journalists' professionalism-defined as the media's professional norms and practices (Benson, 2004; Klinenberg, 2002). Section two examines political parallelism. The third section analyses the role of the state in shaping the functioning of the media system. The final section investigates the influence of economic factors shaping the media market. I conclude by comparing the changing characteristics of the Myanmar media during liberalization to the theoretic expectations outlined in Table 1. 


\section{Discussion}

\subsection{Professionalism}

As outlined in Table 1, Voltmer's theories identify factors closely related to political parallelism as the main obstacles impeding journalistic professionalism during liberalization. Journalists eschew their neutral watchdog role to become opposition activists (bottom-up liberalization) or guard dogs protecting the interests of their economic and political paymasters (top-down liberalization). The media in exile that are a feature of externally-influenced liberalization are also far from neutral, framing their reports to undermine support for the existing regime. Undoubtedly, reporting in the Myanmar media was highly politicized during the country's liberalization. Issues relating to political bias, however, are discussed in the next section on political parallelism.

Interviews for this study reveal that poor education, the influence of social media and ethnic tensions, as well as political factors undermine the application of internationally recognized professional standards in the Myanmar media. Journalists in liberalizing states often poorly understand the norms expected of their profession in a democracy, as for decades state censors externally imposed standards on the media. In many democratizing societies, media organizations are young and inexperienced, since older, more seasoned journalists are often associated with the state-controlled media of the former regime. In 2012, the average Myanmar journalist was 25 (International Media Support, 2012). Even chief editors are unlikely to be much older than 30 . The inexperience of many Myanmar journalists is compounded by a relative lack of professional training opportunities. Journalism schools have only recently appeared and places remain scarce. ${ }^{1}$ There are not enough qualified media professionals to fill the demands of Myanmar's expanding media market. 'Anyone who wants to can get into the media', says a reporter at SkyNet News, herself one of the few at the satellite television channel with a degree in journalism. ${ }^{2}$ State-owned media often pay better salaries than their commercial competitors and therefore attract a larger share of journalism school graduates. Even at leading commercial newspaper Seven Day News, fewer than 10 percent of reporters have a professional qualification. ${ }^{3}$ Competition for qualified journalists and editors increased following the government's decision to allow private newspapers to resume publishing daily editions from 1 April 2013. ${ }^{4}$ A senior editor at Seven Day News explains:
When we decided to run a daily newspaper, we advertised for new reporters. But in most cases the applications we received were not suitable. Some applicants admitted they didn't even read the newspapers. We couldn't find any appropriate candidates to add to our editorial team. We therefore have to edit our daily newspaper with the same number of editors who previously worked at our weekly edition. ${ }^{5}$

Finding qualified media trainers is another challenge, as is accessing training materials in Burmese language. International media training organizations like $B B C$ Media Action and Internews are helping to cover the shortfall in training opportunities by provide professional development courses for Myanmar's journalists both domestically and overseas. But these courses are oversubscribed and usually only last a few months. ${ }^{6}$ Courses provided by international organizations are generally more accessible for journalists in urban centers and/or with English language ability. ${ }^{7}$ During Myanmar's liberalization period, a large number of those being trained by the $B B C$, Associated Press, Kyodo News and other international news agencies worked for state-run media. It is questionable whether training journalists to do a better job promoting the military-backed government's propaganda was helpful to Myanmar's democratization (Moe, 2014). Training opportunities, however, are expanding, with several international organizations targeting courses at journalists from Myanmar's ethnic-minority media. ${ }^{8}$

In states like Myanmar where foreign media were taboo, journalists lack not only adequate training opportunities, but also access to foreign colleagues from whom they could learn international professional norms. By 2012, this situation was improving, as more international journalists and media organizations began to receive government permission to work in Myanmar. But despite growing exposure to international professional standards, ethical norms remained underdeveloped among Myanmar's media professionals. A journalist at Seven Day News estimates that only half of her colleagues understand the meaning of ethical journalism:

In my opinion, 50 percent of journalists behave ethically and 50 percent do not. Many of my junior colleagues confuse fact with opinion and often mix the two in the same article. Sometimes this is not deliberate, but a product of their poor education. But in other cases, journalists deliberately distort the truth to make their reports more sensational. These journalists are more interested being popular and getting

\footnotetext{
${ }^{1}$ Author's interview with Pae Tin Thran editor, December 2013.

2 Author's interview with SkyNet News reporter, December 2013.

${ }^{3}$ Author's interview with Seven Day News editor, December 2013.

${ }^{4}$ All private dailies in Myanmar were shut down in 1964. Until 2013, the authorities allowed publication of state-run dailies, but only permitted the private media to publish weekly editions (Committee to Protect Journalists, 2012).

5 Author's interview with Seven Day News editor December 2014.

${ }^{6}$ Author's interview with Internews trainer, December 2013.

${ }^{7}$ Author's interview with a Yangon-based media trainer, December 2013.

${ }^{8}$ Author's interview with a representative of Burma News International, December 2014.
} 
a lot of followers on Facebook than in accurately reporting the news. ${ }^{9}$

Pursuing financial gain, as well as popularity and fame, can lead journalists to abdicate their professional responsibilities, challenges not accounted for in Voltmer's theories (Table 1). Several interviewees in this study acknowledged bribery as a persistent problem in Myanmar's newsrooms. For example, an editor at Eleven Media admits:

When a new restaurant opens, for example, a reporter might receive money to write a positive review. Sometimes the reporter refuses the money and tells their editor. But other times they take the money. It is difficult to know how often this happens. As an editor, I read 12 to 16 stories a day. Most of the articles I receive aren't good quality and I have to spend a long time on each one to make it publishable. I therefore don't have time to check every fact. ${ }^{10}$

The ethical and professional dilemmas confronting Myanmar's editors are compounded by reliance on citizen journalists with no formal ties to their news organization. In the current Myanmar market, few private media organizations can afford to establish bureaus outside of major cities. As a result, Yangon-based newsrooms often rely on citizen journalists to report on events in remote parts of the country. Lacking any professional education, citizen journalists often fail to record the information necessary to make a story publishable. As an editor at Chin World News explains:

Our entire news organization has only eight full-time staff. We have to rely on citizen journalists and this causes a lot of ethical problems. They contact us with a story, but they have rarely checked who is involved or why it is happening. They don't get the details needed to corroborate a story. We have to tell them to go and ask follow-up questions. But this delays publication of the story. We frequently have to trade timeliness for ethics. ${ }^{11}$

Journalists' poor training and inexperience means that both deliberate and unintended inaccuracies are commonplace in the Myanmar media. Inaccuracies can undermine public confidence in the media and provide authoritarian regimes with a pretext for withdrawing hardwon media freedoms. In Russia, a disregard for professional standards by many journalists allowed President Putin to reassert state control over the broadcast media, a move supported by the majority of Russians (Burrett, 2011). Journalists' poor understanding of profes- sional norms can impair the democratization process. These challenges, absent from Voltmer's theories (Table 1), should be included in theoretical descriptions of the features of the media during liberalization.

The advent of social media creates new ethical quandaries for the media not considered in Voltmer's theories. In 2015, only 12.6 percent of Myanmar's population had access to the Internet (Internet World Stats, 2016). But already social media had become a key news source for urban residents. As one editor explains:

For young people in particular, news shared by friends on Facebook is their main source of information. People don't discriminate between information produced by media professionals or by amateurs. They do not question the origins or authenticity of what they read online. ${ }^{12}$

Several journalists interviewed for this study raised the related issues of fake news and a lack of capacity for critical thinking among audiences as challenges for the Myanmar media. Interviewees stated that audiences were more likely to trust information posted online by their friends than news appearing in the professional media:

The media have a bad reputation. For decades there was only the state media and they were propaganda organs for the government. In post-authoritarian states like Myanmar people tend to trust their friends over institutions, and that includes the media. ${ }^{13}$

Myanmar's multiple ethnic conflicts are the most common theme of fake news, both online and in the traditional media. Journalists lament that new media freedoms won since 2012 have often exacerbate ethnic tensions. Posts on social media precipitated some of the most violent clashes of recent years. Anti-Muslim riots in Mandalay in July 2014, for example, were sparked by a post on Facebook alleging the rape of a Buddhist girl by her Muslim employer. Although the story proved untrue, it quickly went viral, triggering communal violence within 24 hours of posting (Crane, 2014). More attention must be paid to the potential problems posed by social media in theories of the media's role in democratization. Audiences' ability to assess the reliability of online information is a problem everywhere. But it is particularly acute in transitional societies, where authoritarian governments discourage the teaching of critical thinking skills.

False reporting is a problem on both sides in the Buddhist-Muslim conflict in Rakhine. ${ }^{14}$ Owing to problems of access and personal security, it can be difficult for Yangon-based media organizations to verify reports from Myanmar's far-flung regions. At Seven Day News a

\footnotetext{
${ }_{9}^{9}$ Author's interview with Seven Day News reporter, December 2014.

10 Author's interview with Eleven Media editor, December 2013.

11 Author's interview with Chin World News editor, December 2013.

12 Author's Interview with board member of Pen International, March 2015.

13 Author's interview with a Yangon-based media trainer, September 2015.

14 Author's interview with a Yangon-based international media agency correspondent, December 2013.
} 
lack of verification often leads to editors being forced to pull stories from Rakhine:

When a story has a religious or ethnic component we are especially careful about what we write, as we don't want to fuel the conflict. Many times we decide not to print a story because we can't be sure of the facts, or because we can't access opinions on both sides. It is particularly difficult for us to talk to the Rohingya [Muslim] community in Rakhine, since many of them live in government-run refugee camps, which are closed to the media. If we can't print a balanced story, then we don't print any story at all. ${ }^{15}$

Editors may also reject a story on inter-ethnic violence to prevent a backlash from sectarian readers. An editor at Seven Day News explains:

Whenever we write about the conflict in Rakhine we get a lot of angry letters and phone calls, especially from the Arakan (Rakhine Buddhist) side. Following criticism of our reporting on the violence in Rakhine in 2012, we decided to give the issue less prominence. ${ }^{16}$

Self-censorship of this kind can lead to a dearth of balanced information on the causes and consequences of inter-ethnic violence. When balanced reporting is scarce, biased accounts go unchallenged and the probability that the public will be misinformed increases. Several journalists interviewed for this study complained of calculated pro-Buddhist coverage of the 2012 Rakhine conflict by much of the Myanmar media. ${ }^{17}$ As one journalist at Eleven Media said of his colleagues:

Most reporters are Buddhists and they are patriotic. Their personal nationalism is reflected in what they write. This isn't only true of reporting on the Rohingya issue, but also of coverage of international affairs, especially bi-lateral relations with China. ${ }^{18}$

Although patriotic fervor is not uncommon among journalists in other places at times of national crisis-for example in the US following the terrorist attacks on 9/11it is particularly dangerous in the context of volatile interethnic tensions (Kull, Clay, \& Evans, 2003; Levy \& Bugingo, 2001). One-sided reporting not only obscures audiences' understanding of the issues, but also increases the probability of further violence.

Other interviewees in this study attribute biased coverage of ethnic tensions to low educational standards among media professionals. Some argue that biased reporting stems from journalists' poor understanding of media framing. ${ }^{19}$ Framing theory contends that the media focus audience attention on certain events and then place them within a field of meaning. It suggests that how something is presented to the audience influences the choices people make about how to process that information (Entman, 1993; Goffman, 1974; Scheufele, 1999). In Myanmar, by offhandedly using loaded nouns such as 'Bangladeshi' or 'immigrant' to describe the Rohingya, journalists unconsciously framed the Muslim-Buddhist conflict in nationalist terms. ${ }^{20}$

Voltmer's theories identify significant political bias as a feature of media systems undergoing liberalization whether the origins of political change are bottom-up, top-down or external. Her work has less to say about bias arising from ethnic loyalties that may cut across political affiliations. Sectarian biases in media reporting are an impediment to liberalization and should be included in theoretical frameworks. The generals who seized power in Myanmar in 1962 justified their rule as necessary to hold together a country fractured by ethnic strife. Several interviewees for this study raised suspicions that government provocateurs were behind outbreaks of sectarian violence in central Myanmar in 2013. ${ }^{21}$ Fresh sectarian violence adds credence to the military's insistence on remaining a prop to Myanmar's civilian government. But despite harboring suspicions that the military were stoking inter-ethnic tensions to justify retaining power beyond 2015, the majority of journalists were too afraid to publish such concerns. ${ }^{22}$

\subsection{Political Parallelism}

Voltmer's theories predict that when liberalization is initiated from below, the independent media will exhibit a strong pro-opposition bias. But when the process is top-down, the media are more likely to align with factions within the ruling regime. The media are drawn into the escalating conflict between government hard and soft liners over the pace of liberalization. If change is precipitated by external pressure, then exiled and foreign media embolden and widen opposition networks by providing information that challenges the regime's propaganda (Table 1). Unsurprisingly, given the multidirectional sources of its liberalization, Myanmar's media displayed elements of all the features listed above.

In Myanmar, as in other authoritarian states, government persecution of the press led journalists to join pro-democracy groups. During the rule of the military

\footnotetext{
15 Author's interview with Seven Day News editor, December 2013.

16 Author's interview with Seven Day News editor, December 2013.

17 Riots in June 2012 between Rohingya Muslims and Buddhist Rakhine killed approximately 170 and displacing roughly 140,000 mostly Rohingyas.

18 Author's interview with Eleven Media editor, December 2013.

19 Author's interview with Myanmar Journalists Network representative, December 2013.

20 The Rohingyas' exact roots are debated, but many likely settled in Burma in the nineteenth century, having migrated from modern-day Bangladesh following expansion of the British Empire. Today, the Rohingya are excluded from the 135 ethnic groups the government recognizes as Myanmar citizens.

21 Author's interviews with journalists at Mizzima, Seven Day News and Myanmar Freedom Daily, December 2013.

22 Author's interview with Street View Journal journalist, December 2014.
} 
junta, journalists languished in the country's 43 prisons. Even after political reforms began in 2011, the imprisonment of journalists continued (Reporters Sans Frontières, 2012). Harassed by the state, it is difficult for journalists in transitional states to remain neutral observers of political events. Many of Myanmar's journalists are members of the NLD or the ' 88 movement' (Pidduck, 2012). ${ }^{23}$ This is especially true of many of the formermedia-in-exile that began returning to Myanmar following the start of reforms in $2011 .^{24}$ By engaging in political struggles against state leaders, journalist-activists provided the authorities with justification for restricting media freedom. Differences in attitudes between the media and state elites over the proper functioning of the media have led to the rolling back of political reforms and media freedom in Russia, Bolivia, Peru, Guatemala, Sri Lanka, Pakistan, the Philippines and Iraq (Reporters Sans Frontières, 2011/2012).

A politicized media, however, is not incompatible with democracy. In their seminal work on comparative media systems, Hallin and Mancini identify a 'Polarized Pluralism Model' of the media that is dominant in Southern Europe. Under this model, political parallelism, instrumentalism and commentary-orientated journalism dominate the media system (2004, p. 67). External pluralism guarantees that a wide range of political voices can be heard in the public sphere. The rule of law ensures the media freedom from state harassment. But in Myanmar under military-backed rule, opposition media did not face a level playing field with their state-run competitors. Furthermore, pluralism was limited by the legal framework in which the media operated, providing state authorities with a choice of methods for silencing their critics.

Despite some significant political reforms, at the time of the 2015 elections, Myanmar was far from a democratic system. Many journalists therefore contended that it was inappropriate to hold them to the same standards of political neutrality that characterize the media of the established democracies in Europe and North America. A Yangonbased media trainer uses a football metaphor to explain:

Politics in Myanmar is not like in the UK or the US. In the US there are two teams, the Republicans and the Democrats. They compete in the political field where there are rules structuring the game. But in Myanmar we have teams but no agreed rules of the game. First we must build the institutions that structure political competition. This means we must support the prodemocracy movement. Now is not the time for me- dia neutrality. The political system is not neutral; it is stacked in favor of the regime. ${ }^{25}$

How much to accommodate President Thein Sein and other soft liners within his military-backed government was an issue that divided Myanmar's media. Journalists were divided over to what extent they could trust the military's commitment to liberalization. Echoing views expressed by many interviewees, one editor at The Voice supported the idea of a negotiated political settlement with the military, citing the example of South Africa's transition in the 1990s:

A lasting change can only be built slowly and will have to involve the military. I'm not pro-military, but they are a fact of life. A permanent settlement requires a compromise on all sides. Nelson Mandela understood this well. He promoted reconciliation rather than retribution and South Africa today is a consolidated democracy. The opposition in Myanmar must learn that politics is about compromise. When the opposition media aggressively attack the government, it makes the military insecure. ${ }^{26}$

A member of the IPC agreed, arguing that excessive media criticism of the military undermined the likely success of the liberalization process:

It is hard for journalists to imagine the military as vulnerable because for decades the media have been the dictatorship's victims. But in starting the liberalization process, the military are a bit like a mole coming out of his hole for the first time. If he feels safe, he will come out a little further. But if he gets hit on the head, he will run back inside. The military feel like the media are hitting them on the head. ${ }^{27}$

Others in the media disagreed, believing that liberalization was aimed at strengthening the military's hold on power rather than a genuine transition to democracy. A journalist at the formerly exiled satellite broadcaster the Democratic Voice of Burma summed up the views of many of his colleagues:

The military are undertaking reforms to protect themselves. If you are in any doubt, look at how they have guaranteed themselves 25 percent of seats in parliament. This gives them a controlling stake in who is president after $2015 .^{28}$ The military won't give us

\footnotetext{
23 In 1988 demands for an end to the military dictatorship in Myanmar spilled out from university campuses onto the streets, led by a group known as the ' 88 Generation Students' Group. The movement was brutally suppressed and those who were caught were sentenced to decades in prison. Some of those who escaped overseas went on to work in the media in exile.

24 Author's interview with Interim Press Council (IPC) member, December 2014.

${ }^{25}$ Author's interview with Yangon-based media trainer, September 2015.

26 Author's interview with The Voice editor, December 2014.

27 Author's interview with IPC member, September 2015

28 The president of Myanmar is nominated by parliamentarians, not directly elected by the public. Three committees, known collectively as the Presidential Electoral College, are formed from among upper and lower house parliamentarians. One of the three committees is made up entirely of military-appointed lawmakers. Each committee nominates one candidate for the presidency. Members of the Electoral College then vote for one of the three candidates to become president. The candidate with the most votes takes the presidency and the unsuccessful candidates become vice-presidents (Reuters, 2015).
} 
democracy. We must fight for it. They promised democratization in 1990 and we are still waiting. ${ }^{29}$

In line with Voltmer's theories (Table 1), interviewees who had lived in exile were more likely to favor unrestrained struggle against the government than those who had remained in Myanmar. By dividing her theories into three distinct models, however, Voltmer fails to capture the significance of disagreements among journalists over accommodation with the existing regime. Such divisions have allowed authoritarian governments in other places to divide and rule the media (Burrett, 2011).

To build mutual trust, in December 2014, members of the IPC attended the first joint workshop between the military and media to exchange ideas about building an information system that works better for both parties (Zaw, 2014). The IPC explained to General Min Aung Hlaing, the then commander-in-chief of the Myanmar Armed Forces who attended the meeting, that media reporting is often inadvertently biased against the regime due to a lack of freedom of information. Representatives of the military and their civilian colleagues in government were reluctant to talk to journalists. When reporters could not get a quote from official sources, stories often seemed one-sided. ${ }^{30}$ The IPC advised the military to provide more points of contact for journalists in order to improve the public image of the armed forces. Authoritarian authorities' inability to adapt to the demands of the liberalizing media is another factor not included in Voltmer's models.

Journalists interviewed for this study were not only critical of government secrecy, but also of suspicion of the media among Myanmar's opposition parties, especially the NLD. Following the end of pre-publication censorship, photos of Aung San Suu Kyi appeared on newspaper front pages almost daily-something previously unthinkable when her name could not even be mentioned in the press. But most journalists interviewed for this study complained that getting 'the Lady' and her party to comment on the news could be difficult. After decades of government harassment and attempts at infiltration by state agents, the NLD leadership was wary of strangers:

It takes a long time to win the trust of NLD press officers. Even today, government informers try to get inside the party. It is not surprising that they are paranoid, but it makes it hard to get access [to the party]. Only trusted journalists are invited to interview the Lady. $^{31}$

The NLD's reluctance to talk to journalists outside their select circle inhibited reporting on the party's policies and activities in the run up to the 2015 elections. Journalists who criticize the NLD, even with the aim of helping the party improve its operations, found themselves ostracized. The following quotation is typical of the sentiments expressed by many interviewees:

If I criticize the NLD I will be the common enemy of everyone. Sometimes I am more afraid of the NLD than of the military. If I attack the president and the military, my colleagues and readers will approve. They hate the military and are ready to believe the worst of them. But if I criticize the NLD, the party and its supporters will punish me. ${ }^{32}$

Many interviewees also cited over-centralization and a dearth of professional staff as factors hampering the NLD's media operation:

Inside the NLD, the Lady decides everything. Icons do not necessarily make good managers. NLD press conferences are often very chaotic and unprofessional. They don't know how to use the media to their best advantage....A lot of journalists want to help the NLD, but they don't invite us to press conferences. ${ }^{33}$

Several others accuse the NLD of deliberate obfuscation motivated by political expediency:

The Lady is sometimes slow to comment on events because she doesn't want to lose support, for example, over religious conflicts. The NLD focus too much on political issues, like changing the constitution [to allow Aung San Suu Kyi to be president] rather than on the concerns of ordinary people. ${ }^{34}$

Some journalists also felt the NLD did not do enough to oppose flawed new legislation giving the military-backed government continued oversight of the media:

We received very little support from opposition parties in parliament in our struggle with the government over the Media Bill. The Lady's attention was on other matters and NLD MPs take their lead from her. ${ }^{35}$

Strong political support for the NLD among the independent media was not always reciprocated. As elections approached, the military-back government was bent on retaining the legal means to restrain media freedom. Without support from the NLD in parliament, journalist groups possessed few mechanisms through which to oppose legislation aimed at maintaining state influence over the media. Opposition parties' unwillingness

\footnotetext{
${ }^{29}$ Author's interview with Democratic Voice of Burma presenter, December 2014.

30 Author's interview with IPC member, December 2014.

31 Author's interview with a Yangon-based international media agency correspondent, December 2013.

32 Author's interview with Yangon-based print media journalist, July 2015.

33 Author's interview with Yangon-based media trainer and journalist, December 2014.

34 Author's interview with The Chronicle editor, December 2014.

35 Author's interview with IPC member, December 2014.
} 
to work with unfamiliar sympathizers in the independent media and the failure of pro-democracy parliamentarians to support new liberalizing media laws are factors not considered in Voltmer's theories.

\subsection{The State}

As is expected based on Voltmer's theories, when liberalization is largely initiated from above, the political needs of the ruling regime determined the pace and scope of the new freedoms granted to the Myanmar media from 2011 (Table 1). Restrictive media laws remained intact, with journalistic freedom granted at the discretion of the government, rather than by legal statute. In Myanmar, liberalization did not include a new freedom of information law. Journalists complained that government ministry information bureaus were under-staffed and difficult to contact. ${ }^{36}$ Given the brutal and secretive culture of the junta that ruled Myanmar for 50 years, despite liberalization, government officials continued to fear getting into trouble if they talked to the media. Like the rest of society, bureaucrats are traumatized from living under a dictatorship. ${ }^{37}$ The vague wording of national security laws and other laws meant that bureaucrats often felt unsure about what information they could release to the public. Rather than getting into trouble for releasing restricted information, bureaucrats preferred to release nothing. Even when the information pursued by journalists was benign, bureaucrats often stayed silent. ${ }^{38}$

A culture of secrecy, distrust and fear meant government ministries were slow to respond to breaking news stories. In this regard, the military-back government was often 'its own worst enemy'. ${ }^{39}$ Prior to the 2015 elections, the government and military were frequently slow in commenting on stories about ethnic insurgencies. The government's opponents were much faster to respond to media requests for information:

Following an incident, the Kachin Independence Army (KIA) will speak to the media within hours, while it takes the government days to respond. In the old days, the government could release days-old information and no one knew. But now that SIM cards are inexpensive and the Internet is more pervasive, information comes out almost immediately on social media. The first version of a story that appears sets public opinion. The government is very bad at getting their story out to the public. Unfortunately, they usually blame the messenger, accusing the media of being one-sided about Myanmar's civil wars. ${ }^{40}$
Although it was often the military-backed government's secrecy rather than journalistic bias that led to imbalanced reporting of ethnic insurgencies, the authorities used this imbalance to justify cracking down on media freedom. ${ }^{41}$

Government secrecy took a step backwards in August 2014 when hard line Information Minister Ye Htut replaced moderate Aung Kyi (August 2012-July 2014). ${ }^{42}$ Interviewees for this study stated that Ye Htut called editors to criticize their reporting more commonly than his predecessor, pressuring them to change their editorial line. Editors at various newspapers also complained that Ye Htut was less willing to work with the media to solve disputes between the press and authorities than Aung Kyi. Several interviewees speculated that Ye Htut had been appointed to intimidate the media into submission ahead of the 2015 election. Many more journalists were prosecuted and jailed in 2014 and 2015 than in any other year since liberalization began (Nyein, 2014; Stout, 2014).

As Voltmer anticipates when political change is topdown, Myanmar's military-backed government retained a variety of legal means to silence and intimate the media (Table 1). Vague national security laws, such as the 1923 Official Secrets Act, the 1950 Emergency Provisions Act, the 2000 Internet Act, and the 2004 Electronic Transaction Act, ensured that censorship could be legally enforced and journalists punished for non-compliance. The authorities had broad discretion in deciding whether media reports posed a 'threat to national security, domestic tranquility, or racial harmony' (Crane, 2014). While these laws remained mostly unenforced during the reform period from 2012 to 2013, they were utilized as mechanisms of harassment more frequently in 2014 and 2015.

In July 2014, the courts sentenced four reporters and the CEO of current affairs magazine Unity Weekly to ten years in jail with hard labor for publishing an article alleging that Myanmar's military was operating a secret chemical weapons factory in central Myanmar (Committee to Protect Journalists, 2014b). The government used the colonial-era Official Secrets Act to convict the journalists rather than prosecuting them through the new Media Law, passed in March 2014. The new law empowered prosecutors to decide whether to prosecute journalists using the Media Law itself- - which allows for fines but not imprisonment for misdemeanors - or Myanmar's more punitive defamation and national security laws. ${ }^{43}$

In 2014, the Ministry of Information took legal action against two media outlets for defamation. Action was taken against an article on President Thein Sein published by the weekly journal the Myanmar Herald and against a story by Daily Eleven alleging misuse of funds by the

\footnotetext{
36 Author's interview with Irrawaddy editor, December 2014.

37 Author's interview with The Voice journalist, September 2015.

38 Author's interview with Myanmar Freedom Daily reporter, December 2013.

39 Author's interview with Myanmar Freedom Daily reporter, December 2013.

40 Author's interview with Mizzima editor, December 2014.

${ }^{41}$ Author's interview with Yangon Times journalist, December 2013.

42 Author's interview with The Voice editor, December 2014.

43 Author's interview with IPC member, December 2014.
} 
Ministry of Information in its purchase of printing presses (Nyein, 2014). Minor laws were also used to harass journalists. Officials increasingly used the threat of criminal trespassing charges to prevent reporters probing their activities. In April 2014, a DVB journalist was sentenced to one year in jail on charges of 'trespassing' and 'disturbing an on-duty civil servant' while reporting on the seemingly innocuous subject of scholarships awarded to Myanmar students by a Japanese foundation (Committee to Protect Journalists, 2014c). Cases such as this undoubtedly create anxiety within the media community and influence what journalists do and do not report.

In a clear step backwards for media freedom, in March 2014 parliament passed both the Media Act and the Printers and Publishers Regulation Act giving the Ministry of Information ultimate power over what news was permissible to print and sole authority to issue and revoke news publication licenses. Both bills dashed journalists' hopes that new legislation would liberate the media from state intervention. The Printers and Publishers Regulation Act, similar to the previous junta's censorship guidelines, banned the publication of materials that 'insult religion', 'disturb the rule of law', 'violate the constitution', 'incite unrest' or 'harm ethnic unity' (Crispin, 2014). The controversial Act, drafted by the Ministry of Information without consultation with journalist groups, also created a new registrar position with extensive powers to withhold or revoke publishing licenses. Fear of losing their licenses inevitably encouraged selfcensorship among editors, especially in reporting on sensitive topics such as ongoing inter-ethnic tensions and land development. ${ }^{44}$

Government-imposed travel restrictions further impeded reporting on Myanmar's ethnic conflicts during the liberalization period. Journalists were typically barred from areas of unrest. Even when not officially banned, it can be dangerous for journalists to travel to conflict zones, as illustrated by the death of freelancer Aung Kyaw Naing, who died in suspicious circumstances while in military custody after reporting from rebel held territory in Mon State (Committee to Protect Journalists, 2014a). Independent media even faced restrictions on covering outwardly uncontroversial events, such as a visit by the King of Norway to Mandalay in December 2014. Journalists from The Voice, Seven Day News, and $D V B$ were barred from sites along the Irrawaddy River, where dozens of poor families had earlier been evicted to avoid blighting the landscape during the king's visit. $^{45}$ It was not uncommon for the authorities to limit access to diplomatic events and government ceremonies to state-run media to avoid critical coverage. In March 2014, independent media were barred from the firstever press conference by army chief General Min Aung Hlaing, who took questions only from state-owned outlets (Mann, 2014).
As Voltmer's theories predict when liberalization comes in response to external pressures, Myanmar's military-backed government also clamped down on foreign journalists' access (Table 1). In February 2014, the Ministry of Information reduced the duration of foreign reporters' visas from three months with multiple entries to one month with a single entry. The move likely came in reaction to international media criticism of government treatment of Rohingya refugees displaced following ethnic clashes in Rakhine in 2012. In some cases, international reporters were denied entry altogether. In March 2014, for example, Time journalist Hannah Beech was refused a visa, probably in response to her cover story the previous year featuring a radical Myanmar Buddhist Monk with the caption 'The Face of Buddhist Terror' (Crispin, 2014).

\subsection{The Market}

In Myanmar, consistent with Volmter's theories of topdown liberalization, the state continued to dominate the media sector despite marketization (Table 1 ). The independent media that appeared after licensing laws were relaxed depend largely on business elites with government connections for their economic survival. The opposition-operated and foreign-funded media associated with bottom-up and externally-driven liberalization were few in number and limited in influence in Myanmar. Table 3 sets out the financial structures and political connections of Myanmar's main media outlets at the start of 2015.

Prior to the 2015 election, state authorities showed few signs of giving up their controlling influence over the media. The state retained majority control over the television sector, the most popular source of news among urban dwellers. MRTV-4 (owned by the Forever Group) and SkyNet (owned by the Shwe Than Lwin Company) were ostensibly private networks, but were owned by allies of the regime. The formerly exiled satellite broadcaster DVB had a small but growing audience as elections approached. ${ }^{46}$ In August 2015, parliament ratified a new Broadcasting Law, enabling private companies to enter the broadcast market for the first time. Broadcasters were previously required to partner with the state-owned Myanmar Radio and Television (MRTV). The Law, however, maintained government control over the broadcasting sector by granting the president power to appoint members of the new Broadcast Council authorized to issue and revoke broadcast licenses (Freedom House, 2016).

State-owned media also continued to dominate in the print sector. The country's three state-run dailieswhich operated as mouthpieces for the regime-had a circulation of more than 320,000 , while the more popular private newspapers only sold about 80,000 copies per

44 Author's interview with The Chronicle editor, December 2014.

45 Author's interview with The Voice editor, December 2014.

46 Author's interview with DVB editor, December 2014. 
Table 3. Ownership and political connections of main non-state news media (TV and Print), January 2015. Source: Based on information from author's interviews.

\begin{tabular}{llll}
\hline Outlet Name/Type & Parent Company & Funding/ Ownership & Politics \\
\hline 7 Days News & Information Matrix & Thaung Su Nyein & Politically objective despite CEO being the \\
(Weekly \& Daily Print) & Co.Ltd & (CEO) & son of ex-Foreign Affairs Minister Win Aung \\
& & & $\begin{array}{l}\text { (1998-2004). Win Aung was purged from the } \\
\text { government in 2004 and sent to Insein prison, } \\
\end{array}$ \\
& & where he died in 2009.
\end{tabular}

\begin{tabular}{lll}
\hline $\begin{array}{l}\text { Democracy Today } \\
\text { (Weekly \& Daily Print) }\end{array}$ & $\begin{array}{l}\text { Yangon Media } \\
\text { Group }\end{array}$ & $\begin{array}{l}\text { U Ko Ko } \\
\text { Swe Thanj Lwin } \\
\text { (not confirmed) }\end{array}$ \\
\hline $\begin{array}{ll}\text { Democratic Voice } \\
\text { of Burma (TV) }\end{array}$ & $\begin{array}{l}\text { Free Voice of the } \\
\text { Netherlands }\end{array}$ \\
& National \\
& Endowment for \\
& Democracy
\end{tabular}

Close to regime. Promoted President Thein
Sein. Tabloid.

\begin{tabular}{lll}
\hline Eleven (Weekly \& & Eleven Media & Than Htut Aung \\
Daily Print) & Group & (CEO)
\end{tabular}

\begin{tabular}{|c|c|c|c|}
\hline $\begin{array}{l}\text { Irrawaddy (Weekly } \\
\text { \& Monthly Print } \\
\text { English \& Burmese) }\end{array}$ & $\begin{array}{l}\text { Irrawaddy } \\
\text { Publishing Group }\end{array}$ & Aung Zaw & $\begin{array}{l}\text { Owner a former activist who left Myanmar in } \\
\text { 1988. Former media in exile (from 1990). } \\
\text { Returned to Myanmar in 2012. Supportive } \\
\text { of NLD. }\end{array}$ \\
\hline
\end{tabular}

\begin{tabular}{|c|c|c|c|}
\hline Mizzima (Daily \& & Mizzima Media & Serge Pun & Politically independent, former media in exile. \\
\hline Monthly Print) & Group & $\begin{array}{l}\text { Soe Myint } \\
\text { Sonny Swe }\end{array}$ & $\begin{array}{l}\text { Co-owner Soe Myint is a former activist who } \\
\text { hijacked a Thai passenger plane in 1990s to } \\
\text { publicize Myanmar's struggle against its } \\
\text { military regime. Co-owner Serge Pun ranked } \\
\text { No.38 in Forbes Asia's } 2013 \text { rich list } \\
\text { (Chairman SPA Group). }\end{array}$ \\
\hline
\end{tabular}

\begin{tabular}{|c|c|c|c|}
\hline MRTV-4 (TV) & Forever Group & Win Maw & $\begin{array}{l}\text { Generally avoids political reporting. Owner } \\
\text { Win Maw has government connections. }\end{array}$ \\
\hline $\begin{array}{l}\text { Pyi Myanmar } \\
\text { (Weekly \& Daily Print) }\end{array}$ & $\begin{array}{l}\text { Swesone Media } \\
\text { Group }\end{array}$ & Tin Tun Oo & $\begin{array}{l}\text { Politically close to regime. In 2010, owner Tin } \\
\text { Tun Oo stood as a parliamentary candidate } \\
\text { for the military-backed Union Solidarity and } \\
\text { Development Party (USDP). Close to former } \\
\text { Information Minister Kyaw Hsan. Tabloid. }\end{array}$ \\
\hline
\end{tabular}

\begin{tabular}{|c|c|c|c|}
\hline Skynet (Satellite TV) & $\begin{array}{l}\text { Shwe Than Lwin } \\
\text { Company }\end{array}$ & Kyaw Win & $\begin{array}{l}\text { Some pro-regime bias. Owner Kyaw Win has } \\
\text { government connections. }\end{array}$ \\
\hline $\begin{array}{l}\text { Snap Shot (Weekly } \\
\text { Print) }\end{array}$ & & $\begin{array}{l}\text { Myat Khine co- } \\
\text { owner (Editor and } \\
\text { co-owner) } \\
\text { Aung Kyaw Oo } \\
\text { (Financier) }\end{array}$ & $\begin{array}{l}\text { Pro-regime. Co-owner Myat Khine close to } \\
\text { former Information Minister Kyaw Hsan. No } \\
\text { current close government connections. } \\
\text { Tabloid focusing on entertainment news. } \\
\text { Criticized for sensational coverage of } \\
\text { Rakhine conflict. }\end{array}$ \\
\hline $\begin{array}{l}\text { Sun Ray (Weekly, } \\
\text { name changed to } \\
\text { Asian Light, 2014) }\end{array}$ & & $\begin{array}{l}\text { Moe Heina } \\
\text { (not confirmed) } \\
\text { Htaw Kywe } \\
\text { (not confirmed). }\end{array}$ & $\begin{array}{l}\text { Anti-government. Rumored co-owner Moe } \\
\text { Heina former student activist and exile. Now } \\
\text { US citizen. Htaw Kywe also former student } \\
\text { activist. }\end{array}$ \\
\hline
\end{tabular}


Table 3. Ownership and political connections of main non-state news media (TV and Print), January 2015. Source: Based on information from author's interviews. (Cont.)

\begin{tabular}{|c|c|c|c|}
\hline Outlet Name/Type & Parent Company & Funding/ Ownership & Politics \\
\hline $\begin{array}{l}\text { The Myanmar Times } \\
\text { (Weekly Print } \\
\text { English Language) }\end{array}$ & $\begin{array}{l}\text { Myanmar } \\
\text { Consolidate Media }\end{array}$ & $\begin{array}{l}\text { Ross Dunkley } \\
\text { (49 percent) } \\
\text { Thein Tun } \\
\text { (51 percent) }\end{array}$ & $\begin{array}{l}\text { Formerly considered close to the regime, as } \\
\text { part owned by Sonny Swe (See Mizzima), son } \\
\text { of General Thein Swe. }\end{array}$ \\
\hline $\begin{array}{l}\text { The Street View } \\
\text { (Weekly Print) }\end{array}$ & & Toe Naing Mann & $\begin{array}{l}\text { Owner son of Shwe Mann (Speaker of the } \\
\text { lower house 2011-2016), former General and } \\
\text { leading figure in the military government. } \\
\text { Not very political, focused on entertainment. }\end{array}$ \\
\hline $\begin{array}{l}\text { The Voice } \\
\text { (Weekly \& Daily } \\
\text { Print) }\end{array}$ & $\begin{array}{l}\text { Living Color Media } \\
\text { Group }\end{array}$ & $\begin{array}{l}\text { Wife of late Nay } \\
\text { Win Maung } \\
\text { Kyaw Min Swe } \\
\text { (Editor) }\end{array}$ & $\begin{array}{l}\text { Political independent, but often critical of the } \\
\text { government. }\end{array}$ \\
\hline $\begin{array}{l}\text { Yangon Times } \\
\text { (Weekly \& Daily } \\
\text { Print) }\end{array}$ & $\begin{array}{l}\text { Yangon Media } \\
\text { Group }\end{array}$ & $\begin{array}{l}\text { U Ko Ko } \\
\text { (Chairman) }\end{array}$ & $\begin{array}{l}\text { Chairman former Secretary of MWJA } \\
\text { (Myanmar Writers and Journalist } \\
\text { Association), which was close to the Ministry } \\
\text { of Information. From } 2011 \text { gained greater } \\
\text { independence. }\end{array}$ \\
\hline
\end{tabular}

day. ${ }^{47}$ Private outlets could not compete in terms of economic resources, distribution networks or cover price. Operating in a poor country with a modest advertising market, many private media failed to survive. Advertisers often preferred to work with higher-circulation state-run outlets than with the privately-owned media. In 2014, financial difficulties forced three privately owned dailies to close within a month (Cunningham, 2014). A lack of business acumen among those running private newspapers is another factor hampering their success. Trained managers are scarce and many editors are former political prisoners or exiled activists with no business experience. ${ }^{48}$ Financial backers willing to suffer losses while a newspaper establishes a foothold in the market are hard to find. As in other liberalizing states, those with the deepest pockets were often cronies of the regime (Becker, 2004; Heng, 2002; Porto \& Hallin, 2009). Depending on business elites with connections to the government entailed editorial compromise at best. Privatemedia owners used their political leverage to extract economic and regulatory favors from government benefactors in exchange for turning a blind eye to official corruption and failed programs. ${ }^{49} \mathrm{~A}$ few lucky outlets, such as DVB and The Chronicle secured funding from international NGOs, but such sources of finance are limited..$^{50}$

Ties to financial and business interests have restricted what Myanmar's journalists can report about economics as well as politics. Traditionally, the watch- dog role of the media is defined as behavior that reveals abuses in the exercise of state power and ignores the role of the press as a defense against exploitation in the private sphere-most notably with regard to the economy (Chomsky \& Herman, 1988; Donohue, 1995). Clearly, the media should act as a source of redress against the abuse of all forms of power. But in Myanmar, privately owned media outlets have refrained from investigating the activities of the conglomerates to which they belong. At SkyNet, for example, a journalist reports being instructed by editors to refrain from investigating misdemeanors by businesses within the same holding company. ${ }^{51} \mathrm{~A}$ journalist at Mandalay FM was told not to report on any topics that might jeopardize company profits or advertising revenues. ${ }^{52}$

When company profits are not in jeopardy, Myanmar's media have shown a predilection for sensationalism and scandal. Growing competition in the media market has encouraged tabloidization and an emphasis on infotainment over serious news. Myanmar is not alone. In the West, the search for profits in an increasingly crowded market has led to a decline in news quality (Barnett, 1998; Postman, 1986). In democratizing states like Myanmar, where scandal and gossip were previously forbidden, audiences have become transfixed by 'yellow journalism'. ${ }^{53}$ When tabloid newspaper The Sun Rays (Thuriya Naywon) hit the newsstands in 2013, its mixture of colorful cover pages, scandal and sensa-

\footnotetext{
47 Author's interview with IPC member, September 2015.

48 Author's interview with Sun Ray editor, December 2013.

49 Author's interview with People's Age reporter, December 2013.

50 Author's interviews with DVB presenter and The Chronicle editor, December 2013.

51 Author's interview with SkyNet News reporter, December 2013.

52 Author's interview with Mandalay FM reporter, December 2013.

53 Author's interview with Myanmar Times editor, December 2013.
} 
tionalism quickly made it one of the highest circulation weeklies in Yangon. Its no-holds-barred coverage of corruption among high-ranking officials and their cronies in the business elite attracted a wide audience. But the newspaper's personal attacks and unsubstantiated claims quickly landed The Sun Ray in legal hot water. In November 2013, powerful tycoon Tay Za accused the newspaper of defamation after it ran a front-page story with his photo under the headline 'Cronies Should Jump into the Andaman Sea' (Weng \& Zaw, 2013). The following month, the Ministry of Information asked the IPC to take action against the newspaper for its 'unethical yellow journalism' and 'hate speech' (Snaing, 2013). Journalists interviewed for this study were equally critical of The Sun Ray and other tabloids for bringing their profession into disrepute. The following quotation from an Irrawaddy journalist is typical of many:

The Sun Ray is 50 percent gossip. It provides no evidence for its accusations. Its unethical behavior damages public confidence in the media and allows the government to say we need restrictions on what journalists can report. ${ }^{54}$

Other journalists expressed concern that the success of The Sun Ray and fellow tabloids, such as Snap Shot, would encourage more newspapers to adopt a sensationalist style.

Some interviewees expressed suspicions that more sinister motives lay behind the tabloidization of the press. Although it appeared that by exposing state corruption tabloids were living up to their watchdog role, such stories concealed political biases, as a member of the IPC explains:

Look closely and you will realize that some newspapers only attack members of a particular faction within the regime. Their victims are carefully chosen. ${ }^{55}$

As is predicted by Voltmer's theories when liberalization is predominately top-down, ownership of much of the Myanmar media by figures close to the military-backed regime means that reporting on government corruption was often a by-product of intra-elite conflict rather than the result of a commitment to the public interest ( $\mathrm{Ta}$ ble 1). Similar 'information wars' between competing elites in post-Soviet Russia badly damaged public confidence in the media. Journalists' complicity in the information wars of the 1990s strengthened public support for President Putin's increase in state control of the media from 2000 (Burrett, 2011). Although often an obstacle to successful democratization, the tabloidization of the media that invariably accompanies liberalization is not included in Voltmer's theories (Table 1).

My recommendations for additions and amendments to Voltmer's theories based on my analysis of the
Myanmar media are summarized in Table 4 and in the concluding section below.

\section{Conclusion}

During the five-year liberalization period preceding parliamentary elections in November 2015, to a greater or lesser extent, all of the media features and functions predicted by Voltmer's theories were present in Myanmar. Looking again at Table 1, the Myanmar media strongly exhibited features associated with both top-down and bottom-up liberalization. Although less significant, elements derived from externally-induced liberalization were also present. Programs broadcast from abroad by, for example, $D V B$, Radio Free Asia and the $B B C$ were popular. But there is little evidence that exposure to transnational media content by itself mobilized popular resistance to the regime. News from overseas of international solidary with Myanmar's pro-democracy movement, however, may have helped strength the resolve of opposition activists in their struggle against the regime (Puddington, 2000).

Although Volmer's tripartite theory is helpful in analyzing the media' role in Myanmar's liberalization, the complex causes of the country's political transformation suggest that the distinctions between her three discreet models are becoming obsolete. Voltmer acknowledges that democratic transformations often contain elements from more than one model. Innovations in online media, however, are accelerating interdependence between the forces driving liberalization. The presence of social media brings greater potential for grassroots participation and coordination that are part of bottomup transformations (Krastev \& Holmes, 2012). Growing Internet access provides foreign and exiled media alternatives to state-run news, increasing the role of external forces in pushing domestic change. Furthermore, prodemocracy activists can use online tools to draw global attention to government brutality and to pressure the international community to support their calls for democracy. External pressure and domestic activism can convince ruling regimes to initiate top-down reforms. Given the growing interdependence between the forces driving liberalization, it may be better to collapse Voltmer's three models into one.

Applying Voltmer's models to the Myanmar media highlights several omissions in her theories. In Table 4, I recommend additional features for inclusion in each dimension of the media system, regardless of the source of liberalization. The features I identify cut across Voltmer's three models. Myanmar's experience suggests these additional features are factors potentially influencing the media's actions, regardless of whether liberalization is precipitated by bottom-up, top-down or external forces. Voltmer's focus on politics as the catalyst for change leads her to omit some of the practical challenges that

\footnotetext{
54 Author's interview with Irrawaddy journalist, December 2013.

55 Author's interview with IPC member, December 2013.
} 
Table 4. Amended features and functions of the media system during liberalization (recommendations for addition are highlighted in blue).

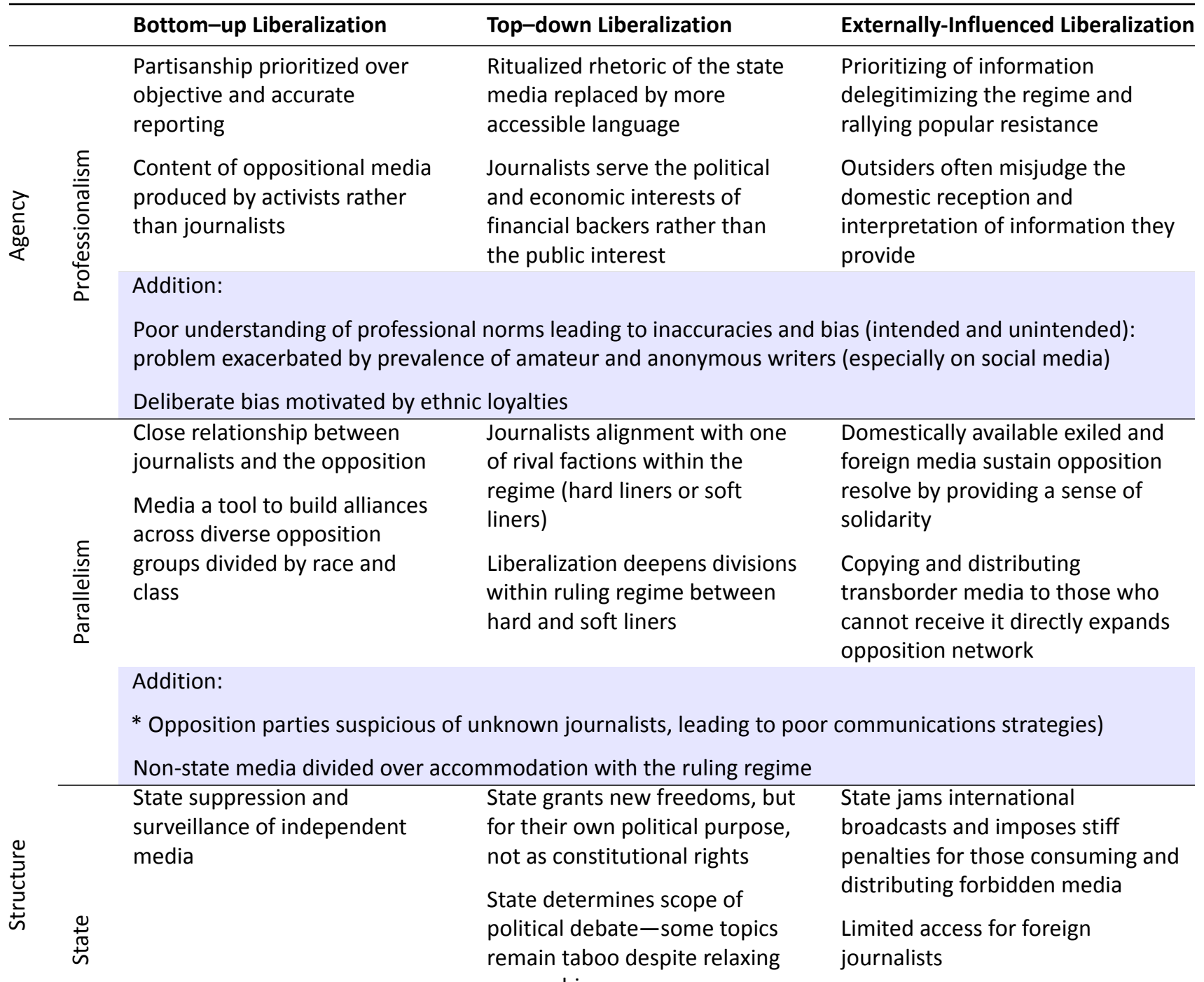

\begin{tabular}{|c|c|c|c|}
\hline & \multirow{2}{*}{\multicolumn{3}{|c|}{ Addition: }} \\
\hline & & & \\
\hline & \multicolumn{3}{|c|}{ State lacks capacity and knowhow to improve communications with the public via the media } \\
\hline \multirow{4}{*}{ 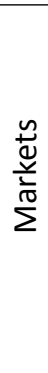 } & \multirow{2}{*}{$\begin{array}{l}\text { Pro-democracy opposition } \\
\text { have their own media } \\
\text { (including dissident and } \\
\text { underground media) that } \\
\text { challenge state media } \\
\text { narratives }\end{array}$} & $\begin{array}{l}\text { State-controlled media persists, } \\
\text { despite marketization } \\
\text { delivering some pluralism }\end{array}$ & $\begin{array}{l}\text { Opposition (including media) } \\
\text { funded by foreign donors and } \\
\text { political exiles }\end{array}$ \\
\hline & & $\begin{array}{l}\text { Independent media largely } \\
\text { dependent on intra-regime } \\
\text { factions for economic survival }\end{array}$ & $\begin{array}{l}\text { Foreign media available in the } \\
\text { domestic market }\end{array}$ \\
\hline & \multicolumn{3}{|l|}{ Addition: } \\
\hline & \multicolumn{3}{|c|}{ Tabloidization undermines quality of information and public confidence in the media } \\
\hline
\end{tabular}

frequently undermine journalistic professionalism during liberalization. The youth and inexperience of those drawn into journalism as the media expands under liberalization have negative consequences for professional standards and ethics that can in turn impede the liberalization process. These challenges are exacerbated by the accessibility and anonymity afforded by social media. In the presence of civil conflict, ethnic or religious loyalties can further encourage journalists to abdicate their professional responsibilities.

Political parallelism was a significant factor influencing the features and functions of the Myanmar media. As expected by Voltmer when societal demands from below are a cause of liberalization, much of the nonstate media in Myanmar was found to support the pro-democracy opposition. Many Myanmar journalists 
viewed themselves as activists rather than as neutral observers of events, as liberal models of journalism would suggest. Although some journalists were close to the opposition NLD, others outside the party's tightknit circle were treated with suspicion, despite sharing its pro-democracy aims. In Myanmar's highly partisan environment, journalists seeking to hold the opposition, as well as the government, to account were ostracized by both sides. The NLD's suspicion of strangers sharing their democratic sympathies suggests Voltmer's claims of close relations between the opposition and independent media requires qualification (Table 4).

Myanmar's liberalization was initiated from above as well as from below. Like authoritarian leaders in China and the Soviet Union, Myanmar's military-backed government pursued liberalization to mitigate societal demands for political change that might otherwise become difficult to control (Mickiewicz, 1997; Steinhardt, 2010). The media were granted new freedoms as a means for the regime to achieve its broader policy objectives, most notably to end Western sanctions. New freedoms were not constitutionally guaranteed. Given the uneven playing field, Myanmar's journalists differed over how much to accommodate the ruling regime. Some journalists supported unrestrained struggle, while other supported cautious compromise. Those willing to meet the military half way did not align with regime soft liners as Voltmer's theories predict. Rather these journalists saw reconciliation with the military as the only means to building lasting peace and democracy. This more nuanced understanding of journalists' motives for sometimes working with the regime is included in my suggestions for refining Voltmer's theories in Table 4.

Although liberalization expanded the range of issues open for critical discussion in the media, the state continued to determine the scope of debate. Despite the abolition of official censorship in 2012, the state retained significant legal means to coerce the media, fostering a culture of self-censorship. Travel restrictions limited access to trouble spots by domestic and international journalists. A culture of suppression and secrecy endured within state institutions despite reforms. Interviewees for this study, however, assert that the state's lack of capacity for effective communications in part accounts for its ongoing culture of secrecy. The state's inexperience and weakness at public relations are not mentioned by Voltmer, but are included in my recommendations for expanding her theories in Table 4.

Despite introducing commercialization, the state remained the main player in Myanmar's media market during the country's liberalization. Financing from international donors and other independent revenue streams were minor in comparison to the economic resources of the state and its business allies. Opposition-operated media were low in circulation and consumed mainly by the converted. Although often serving the political and economic interests of their owners, commercial-media outlets acted as a counterweight to pronouncement in the state-owned media. But as combatants in the factional wars within the ruling regime the commercial media were limited in their watchdog role. The tabloidization unleashed by marketization curtailed the media's ability to encourage societal reconciliation and to present political alternatives, important functions in an emerging democracy. The negative repercussions of tabloidization are not accounted for in Voltmer's theories. Their addition to her framework is my last recommendation in Table 4.

Voltmer's theories provide a useful framework for understanding the media's role as a subject and agent of change in Myanmar's liberalization. At the same time, as a case study, Myanmar provides insights into how these theories might be expanded and refined in the future. The inauguration of a new government in 2016 notwithstanding, many obstacles remain to achieving a genuinely free media in Myanmar. Some of these challenges, such as self-censorship, are hangovers from the junta period, while others, such as tabloidization, are products of liberalization. The Myanmar media has never functioned as a democratic fourth estate. But although the range of views on offer is far from complete and the operation of the market deeply flawed, the media today provide Myanmar audiences with a form of imperfect pluralism on which to build a more democratic future.

\section{Acknowledgements}

I am grateful to Temple University Faculty Senate and Sophia University, Japan for funding my fieldwork for this study. I would like to thank Becky Palmstrom and Jeff Kingston for their help in arranging interviews and Sunny Gladish and Hoang Thu Trang Le for their assistance with transcription.

\section{Conflict of Interests}

The author declares no conflict of interests.

\section{References}

Barnett, S. (1998). Dumbing down or reaching out: It was tabloidisation wot done it. In J. Seaton (Ed.), Politics and the media: Harlots and prerogatives at the turn of the millennium. Oxford: Blackwell.

Becker, J. (2004). Lessons from Russia: A neo-authoritarian media system. European Journal of Communication, 19(2), 139-163.

Benson, R. (2004). Bringing the sociology of media back in. Political Communication, 21(3), 275-292.

Burrett, T. (2011). Television and presidential power in Putin's Russia. London: Routledge.

Carothers, T. (2002). The end of the transition paradigm. Journal of Democracy, 13(1), 6-21.

Chomsky, N., \& Herman, E. S. (1988). Manufacturing consent: The political economy of the mass media. New York, NY: Pantheon Books. 
Committee to Protect Journalists. (2012, December 28). Burmese government allows dailies to resume publishing. Committee to Protect Journalists. Retrieved from https://www.cpj.org/2012/12/burmese-govern ment-allows-dailies-to-resume-publis.php

Committee to Protect Journalists. (2014a, October). Aung Kyaw Naing, "Par Gyi". Committee to Protect Journalists. Retrieved from https://cpj.org/killed/ 2014/aung-kyaw-naing-par-gyi.php

Committee to Protect Journalists. (2014b, July 10). Burma takes another step toward repressing its media. Committee to Protect Journalists. Retrieved from https://cpj.org/2014/07/burma-takes-another -step-toward-repressing-its-med.php

Committee to Protect Journalists. (2014c, April 7). Amid rising repression, Burmese journalist given jail term. Committee to Protect Journalists. Retrieved from https://cpj.org/2014/04/amid-rising-re pression-burmese-journalist-given-ja.php

Crane, B. (2014, December 5). Burma backtracks on press freedoms. American Interest. Retrieved from www.the-american-interest.com/2014/12/05/burma -backtracks-on-press-freedoms

Crispin, S. (2014, March 14). Burma's clampdown gather's pace as legislation passes. Committee to Protect Journalists. Retrieved from https://cpj.org/blog/ 2014/03/burma-clampdown-gathers-pace-as-legisla tion-passed.php

Cunningham, S. (2014, April 5). Third daily Burmese newspaper shuts down, but more to come. Forbes. Retrieved from www.forbes.com/sites/susancun ningham/2014/04/05/a-third-daily-newspaper-shuts -down-in-myanmar

Dahl, R. (1998). On democracy. New Haven, CT: Yale University Press.

Donohue, G. (1995). A guard dog perspective on the role of media. Journal of Communication, 45(2), 115-132.

Entman, R. M. (1993). Framing: Toward clarification of a fractured paradigm. Journal of Communication, 42(4), 51-58.

Freedom House. (2016). Freedom House Report 2016. Freedom House. Retrieved from https://freedom house.org/report/freedom-press/2016/myanmar

Goffman, E. (1974). Frame analysis: An essay on the organization of experience. New York, NY: Harper and Row.

Hallin, D., \& Mancini, P. (2004). Comparing media systems: Three models of media and politics. New York, NY: Cambridge University Press.

Harris, M. (2013, July). Burma: Freedom of expression in transition. Index on Censorship. Retrieved from www.indexoncensorship.org/2013/07/burmafreedom-of-expression-introduction

Heng, R. H. (2002). Media fortunes, changing times: ASEAN states in transition. Singapore: Institute of Southeast Asian Studies.

Hlaing, K. Y. (2012). Understanding recent political changes in Myanmar. Contemporary Southeast Asia, 34(2), 197-216.
Human Rights Watch. (2015, January 29). Burma: Rights heading in wrong direction. Human Rights Watch. Retrieved from www.hrw.org/news/2015/01/29/ burma-rights-heading-wrong-direction

International Media Support. (2012, January). An assessment of media challenges and opportunities in Myanmar: Change is in the air. International Media Support. Retrieved from www.mediasupport.org/ publication/myanmar-change-is-in-the-air

Internet World Stats. (2016) Myanmar: Internet usage, broadband and telecommunications reports. Retrieved from http://www.internetworldstats.com/ asia/mm.htm

Klinenberg, E. (2002). Heat wave: A social autopsy of disaster in Chicago. Chicago, IL: University of Chicago Press.

Krastev, I., \& Holmes, S. (2012). An autopsy of managed democracy. Journal of Democracy, 23(3), 33-45.

Kull, S., Clay, R., \& Evans, L. (2003). Misperceptions, the media, and the Iraq war. Political Science Quarterly, 118(4), 569-598.

Levy, A., \& Bugingo, F. (2001, October 11). Between the pull of patriotism and self-censorship. Reporters Sans Frontières. Retrieved from https://rsf.org/ en/reports/between-pull-patriotism-and-self-censor shipthe-us-media-torment-after-11-september

Mann, Z. (2014, December 5). Mandalay authorities hassle independent media during Norwegian King's arrival. The Irrawaddy. Retrieved from www.irrawaddy. org/burma/independent-media-banned-covering-nor wegian-kings-mandalay-arrival.html

Mickiewicz, E. (1997). Changing channels: Television and the struggle for power in Russia. Oxford: Oxford University Press.

Moe, K. Z. (2014, July 3). Myanmar needs independent media, not 'public service' propaganda. The Irrawaddy. Retrieved from www.irrawaddy.org/maga zine/myanmar-needs-independent-media-public-ser vice-propaganda.html

Nyein, N. (2014, September 23). Burma's going to bring defamation charges against 2 publications. The Irrawaddy. Retrieved from www.irrawaddy.org/bur $\mathrm{ma}$ /burmas-govt-bring-defamation-charges-2-public ations.html

O’Donnell, G., \& Schmitter, P. (1986). Transitions from authoritarian rule: Tentative conclusions about uncertain democracies. Baltimore, MD: John Hopkins University Press.

Pidduck, J. (2012). Exile media, global news flows and democratization: The role of democratic voice of Burma in Burma's 2010 elections. Media, Culture \& Society, 34(5), 537-553.

Porto, M., \& Hallin, D. (2009). Media and democratization in Latin America. The International Journal of Press/Politics, 14(3), 291-295.

Postman, N. (1986). Amusing ourselves to death: Public discourse in the age of show business. London: Heinemann. 
Puddington, A. (2000). Broadcasting freedom: The Cold War triumph of radio free Europe and radio liberty. Lexington: University of Kentucky.

Reporters Sans Frontières. (2011/2012). Press freedom index 2011-2012. Reporters Sans Frontières. Retrieved from https://rsf.org/en/world-press-free dom-index-20112012

Reporters Sans Frontières. (2012, December). Burmese media spring. Reporters Sans Frontières. Retrieved from https://rsf.org/en/news/how-long-will-burmese -media-spring-last

Reuters. (2015, January 31). FACTBOX-Myanmar's new political structure. Reuters. Retrieved from http://in.reuters.com/article/2011/01/31/idINIndia54526820110131 ?pageNumber $=1$

Scheufele, D. (1999). Framing as a theory of media effects. Journal of Communication, 49(4), 103-122.

Schneider, C., \& Schmitter, P. (2004). Liberalization, transition and consolidation: Measuring the components of democratization. Democratization, 11(5), 59-90.

Snaing, Y. (2013, December 13). Ministry urges press council to take action against journal. The Irrawaddy. Retrieved from http://www.irrawaddy.org/burma/ ministry-urges-press-council-take-action-journal.html
Steinhardt, H. C. (2010). From blind spot to media spotlight: Propaganda policy, media activism and the emergence of protest events in the Chinese public sphere. Asian Studies Review, 39(1), 119-137.

Stout, D. (2014, July 11). Burmese journalists sentenced to a decade in prison with hard labor. Time. Retrieved from http://time.com/2974972/burma-media-journ alists-unity-weekly

Tha, K. P. (2014, November 5). US 'too optimistic' about Burma reform: Suu Kyi. The Irrawaddy. Retrieved from www.irrawaddy.org/burma/us-optimistic-bur ma-reform-suu-kyi.html

Voltmer, K. (2013). The media in transitional democracies. Cambridge: Polity Press.

Weng, L., \& Zaw, H. N. (2013, November 26). Tycoon sues journal on defamation charges. The Irrawaddy. Retrieved from www.irrawaddy.org/burma/tycoonsues-journal-defamation-charges.html

Zaw, N. (2014, November 28). Information access on agenda as media prepare for military meeting. The Irrawaddy. Retrieved from www.irrawaddy.org/bur ma/information-access-agenda-media-prepare-milit ary-meeting.html

\section{About the Author}

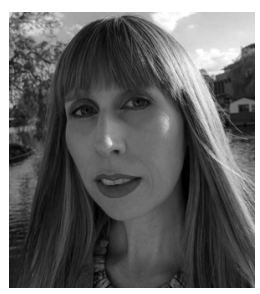

Tina Burrett is Associate Professor of Political Science at the Faculty of Liberal Arts, Sophia University, Japan. She holds a PhD in Political and Social Sciences from Cambridge University. Her publications include Television and Presidential Power in Putin's Russia, (Routledge, 2013, paperback), "Spin over Substance? The PR Strategies of Vladimir Putin and Abe Shinzo" in Freedom of the Press in Contemporary Japan, edited by Jeff Kingston (Routledge, 2016), "Abe Road: Comparing Japanese Prime Minister Shinzo Abe's Leadership of his First and Second Governments", in the Parliamentary Affairs (2017) and Prime Ministerial Leadership in Britain and Japan, (Palgrave Macmillan, 2018, forthcoming). 